\title{
BMJ Global Health COVID-19 response by the Hopi Tribe: impact of systems improvement during the first wave on the second wave of the pandemic
}

\author{
Duane Humeyestewa, ${ }^{1}$ Rachel M. Burke (D) , ${ }^{2}$ Harpriya Kaur, ${ }^{2,3}$ Darren Vicenti, ${ }^{4}$ \\ Royce Jenkins, ${ }^{1}$ Graydon Yatabe, ${ }^{2}$ Jocelyn Hirschman, ${ }^{4}$ Joyce Hamilton, ${ }^{1}$ \\ Kathleen Fazekas, ${ }^{2}$ Gary Leslie, ${ }^{4}$ Gregory Sehongva, ${ }^{1}$ Kay Honanie, ${ }^{4}$ Edison Tu'tsi, ${ }^{1}$ \\ Oren Mayer, ${ }^{2}$ Michelle Ann Rose, ${ }^{2}$ Yvette Diallo, ${ }^{2}$ Scott Damon, ${ }^{2}$ \\ Leah Zilversmit Pao, ${ }^{2} \mathrm{H}$ Mac McCraw, ${ }^{2}$ Bruce Talawyma, ${ }^{1}$ Mose Herne,${ }^{4}$ \\ Timothy L Nuvangyaoma, ${ }^{1}$ Seh Welch, ${ }^{2}$ S Arunmozhi Balajee ${ }^{2}$
}

To cite: Humeyestewa D, Burke RM, Kaur $\mathrm{H}$, et al. COVID-19 response by the Hopi Tribe: impact of systems improvement during the first wave on the second wave of the pandemic. BMJ Global Health 2021;6:e005150. doi:10.1136/ bmjgh-2021-005150

Handling editor Seye Abimbola

- Additional supplemental material is published online only. To view, please visit the journal online (http://dx.doi.org/10. 1136/bmjgh-2021-005150).

Received 27 January 2021 Revised 6 April 2021 Accepted 16 April 2021

Check for updates

C A Author(s) (or their employer(s)) 2021. Re-use permitted under CC BY-NC. No commercial re-use. See rights and permissions. Published by BMJ.

For numbered affiliations see end of article.

\section{Correspondence to}

Dr Rachel M. Burke;

Ixx8@cdc.gov and

Mr Duane Humeyestewa;

DHumeyestewa@hopi.nsn.us

\section{ABSTRACT}

The Hopi Tribe is a sovereign nation home to $\sim 7500 \mathrm{Hopi}$ persons living primarily in 12 remote villages. The Hopi

Tribe, like many other American Indian nations, has been disproportionately affected by COVID-19. On 18 May 2020, a team from the US Centers for Disease Control and Prevention (CDC) was deployed on the request of the tribe in response to increases in COVID-19 cases. Collaborating with Hopi Health Care Center (the reservation's federally run Indian Health Service health facility) and CDC, the Hopi strengthened public health systems and response capacity from May to August including: (1) implementing routine COVID-19 surveillance reporting; (2) establishing the Hopi Incident Management Authority for rapid coordination and implementation of response activities across partners; (3) implementing a community surveillance programme to facilitate early case detection and educate communities on COVID-19 prevention; and (4) applying innovative communication strategies to encourage mask wearing, hand hygiene and physical distancing. These efforts, as well as community adherence to mitigation measures, helped to drive down cases in August. As cases increased in September-November, the improved capacity gained during the first wave of the pandemic enabled the Hopi leadership to have real-time awareness of the changing epidemiological landscape. This prompted rapid response coordination, swift scale up of health communications and redeployment of the community surveillance programme. The Hopi experience in strengthening their public health systems to better confront COVID-19 may be informative to other indigenous peoples as they also respond to COVID-19 within the context of disproportionate burden.

\section{INTRODUCTION}

The Hopi Tribe is a sovereign nation located on $\sim 1.5$ million acres in a rural/frontier area in northeastern Arizona. The Hopi reservation, home to 7500 enrolled Hopi and
Summary box

During May-August 2020, the Hopi Tribe intensively collaborated with partners to improve the Hopi public health system and thus increase capacity to respond to COVID-19.

- Timely access to relevant data (ie, data specific to the Hopi population) was a critical element facilitating rapid response to the pandemic, especially for a small and close-knit population vulnerable to imported cases and subsequent community spread.

- Implementation of a response leadership body enabled coordination of response efforts across multiple partners, enhancing efficiency of operations.

- Innovative and culturally tailored health messages and communication strategies, including a community-focused house-to-house programme, helped to encourage community members to adhere to COVID-19 mitigation guidelines.

- Overall, this multipronged approach, informed by local data and tailored to the unique cultural context of the Hopi, may have helped the tribe to drive down cases and interrupt community transmission in August-September.

Hopi-Tewa members, encompasses 12 villages of varying sizes and several communities and is completely surrounded by the Navajo Nation (figure 1). ${ }^{1}$ The Hopi Tribe is governed by a Tribal Council, which represents the tribe to local, federal and state governments, as well as to other tribes; however, each Hopi village has its own governing structure and individual authority over its borders. There is one healthcare facility on the reservation, Hopi Health Care Center (HHCC), an Indian Health Service (IHS) critical access hospital. (The IHS provides healthcare services to American 

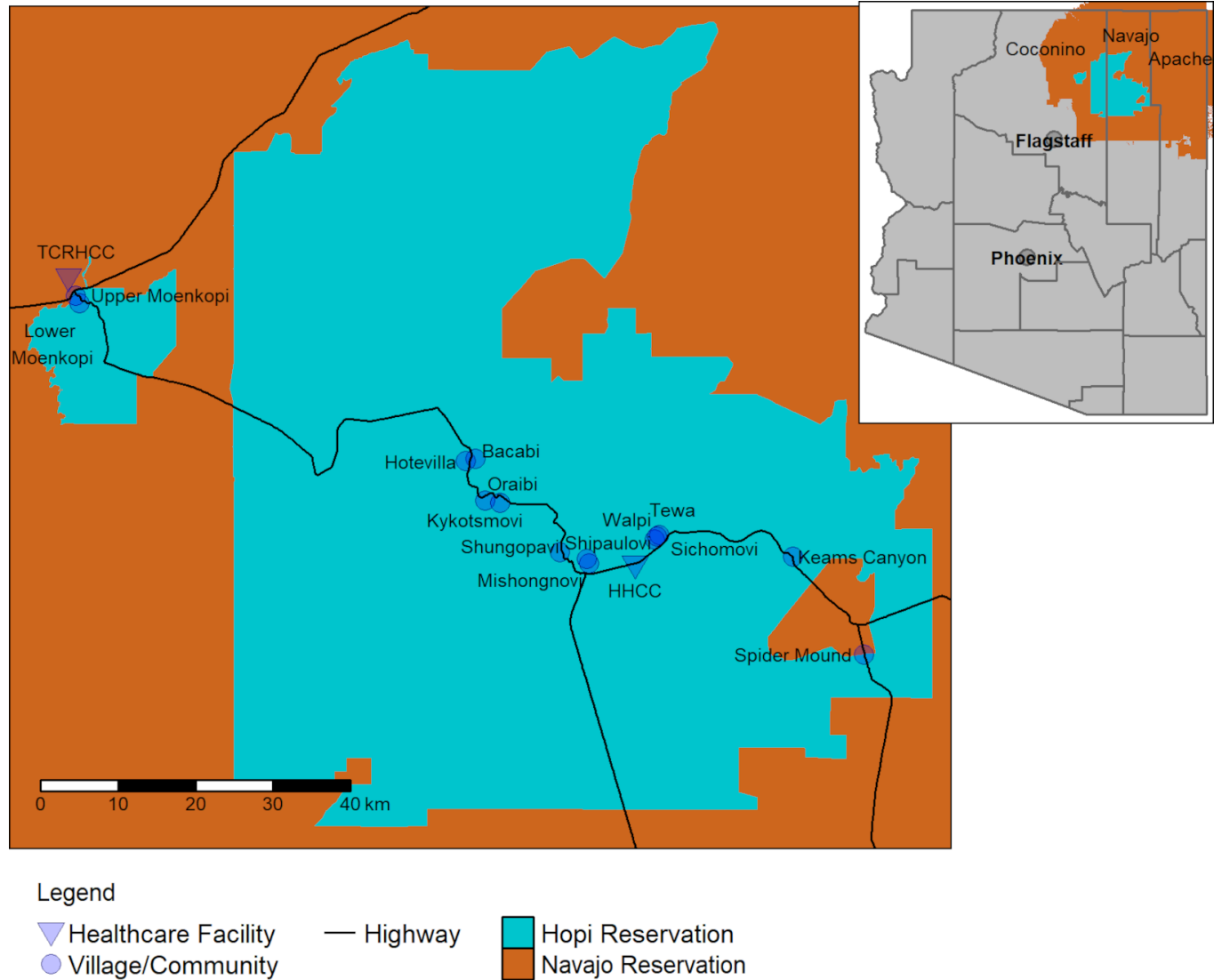

Figure 1 Map of Hopi villages and communities with Arizona inset. The state of Arizona is represented by grey on the inset map. The cities of Phoenix (the state capital) and Flagstaff (the closest city with a population $>75000$ ) are indicated, as well as the counties in the state. Counties neighbouring the Hopi reservation (Navajo, Apache and Coconino) are labelled.

Indians and Alaska Natives, with no associated charges to the individuals served. These services are provided as part of the unique government-to-government relationship of the USA to federally recognised tribes.) However, some individuals seek care at other healthcare facilities for reasons of personal preference or convenience. Specifically, persons living in the western non-contiguous section of the reservation often seek care at the Tuba City Regional Health Care Corporation (TCRHCC), which is run by the Navajo Nation and which is geographically closer than HHCC. All Hopi are eligible for free healthcare at IHS-run (eg, HHCC) or tribally managed (eg, TCRHCC) facilities.

In the USA, the COVID-19 pandemic has disproportionately affected American Indian and Alaska Native persons. ${ }^{23}$ The reasons for this disparity are multifactorial: American Indian and Alaska Natives have suffered long-standing inequities in public funding, resulting in inadequate public health capacity, healthcare access and basic infrastructure among many tribes. ${ }^{4-8}$ Furthermore, insufficient access to healthcare, education, stable housing and healthy foods, along with historical trauma, have contributed to health disparities (including higher prevalence of smoking, obesity, diabetes and cardiovascular disease) that put indigenous peoples at higher risk for severe COVID-19 associated illness. ${ }^{7} 10$ Many American Indians and Alaska Natives live in multigenerational homes in remote areas, which can present unique challenges to mitigating the spread of disease in their communities. Among the Hopi, many live in rural/frontier areas and may lack indoor plumbing, cell phone service, internet, transportation and nearby healthcare facilities. ${ }^{69}$ Navigating the COVID-19 response in these settings requires creative solutions adapted to available resources as well as the specific cultural context. ${ }^{11}$

In this manuscript, we discuss the timeline of the outbreak and response on the Hopi reservation in two phases: from mid-March to mid-August 2020 (first wave), during which the Hopi Tribe collaborated with federal partners to strengthen public health systems and response infrastructure, and from mid-August 2020 to mid-November 2020 (second wave), when these systems were tested by rising cases during the second wave seen across the USA in autumn 2020.

\section{THE FIRST WAVE}

\section{Epidemiological overview}

On 23 March 2020, in response to increasing cases of COVID-19 in surrounding areas, the Hopi Tribe issued a stay-at-home order closing all except essential businesses and directing residents to stay home except for the conduct of essential activities such as obtaining food or medical care (https://www.hopi-nsn.gov/wp-content/ 


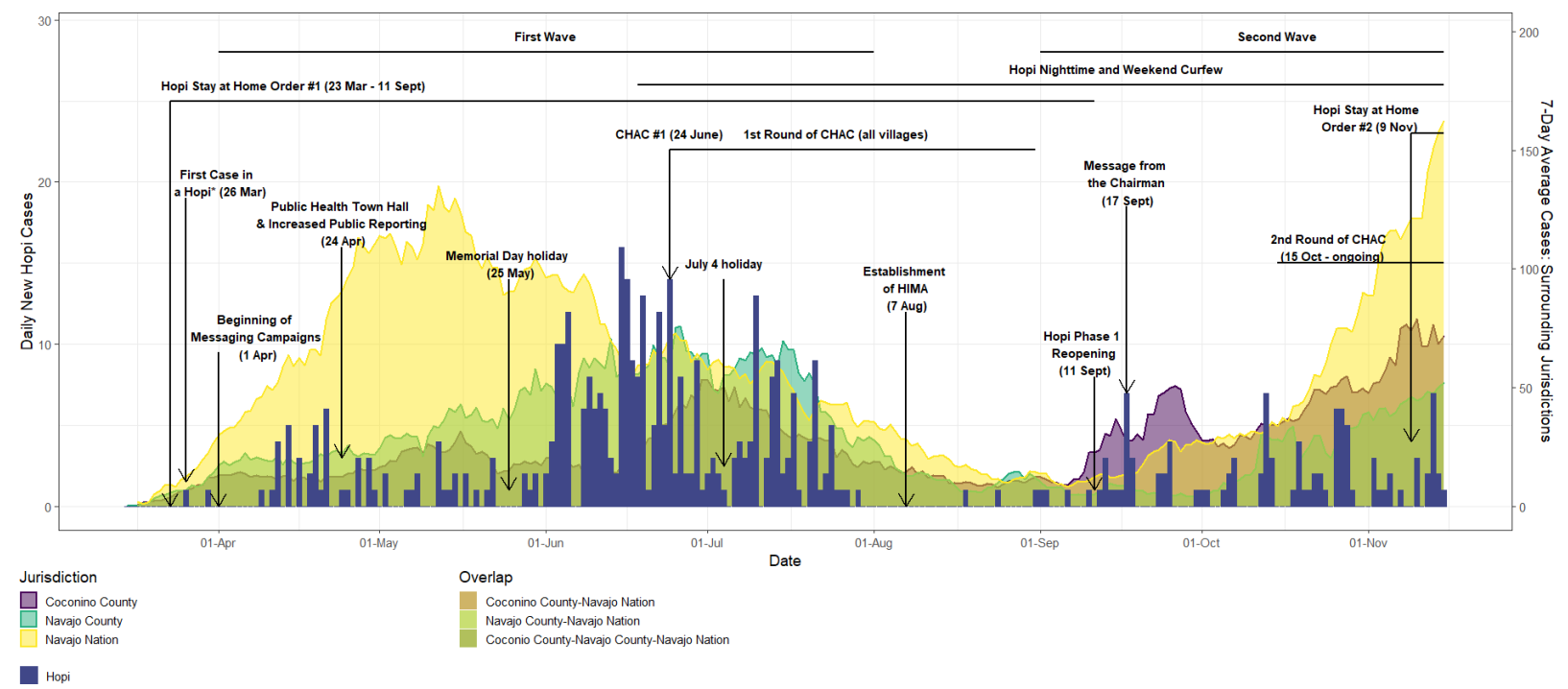

Figure 2 Key events overlaid on Hopi COVID-19 case counts and smoothed case counts for Coconino and Navajo counties and Navajo Nation. Hopi cases include cases diagnosed in persons of Hopi tribal enrolment (regardless of community of residence) and cases diagnosed in persons living on the Hopi reservation (regardless of tribal enrolment); cases diagnosed at Hopi Health Care Center or Tuba City Regional Health Care Corporation are presented, with date corresponding to the date of sample collection. Hopi case counts are presented as blue bars with scale corresponding to the left y-axis. Smoothed case counts (7-day rolling averages) for Coconino and Navajo counties, as well as Navajo Nation, are presented as semitransparent area (purple, green and yellow, respectively) with scale corresponding to the right y-axis. Semitransparent areas overlap in some cases. Hopi cases are a subset of cases in the surrounding Coconino and Navajo counties but are separate from Navajo Nation cases. Navajo Nation cases include cases in the surrounding Coconino and Navajo counties but also include cases from other counties; they have no overlap with Hopi cases. CHAC, Community Outreach, Health Education, Assessment for COVID-19, Connection to Testing and Care (community outreach programme).

uploads/2020/03/Exec.-Order-002-2020.pdf) (figure 2). The first confirmed case of COVID-19 in a Hopi resident was reported on 28 March 2020; between April and May, cases continued to be diagnosed at low levels. Average daily incidence (using a moving 7-day average case count) among Hopi peaked in mid-June at $>100$ cases per 100000 population (average eight to nine new cases per day), declined, and then peaked again in mid-July. During June and July, cases in the surrounding Navajo Nation were declining from their peak in mid-May ${ }^{13}$ but were still elevated, whereas cases in Coconino and Navajo counties overall (which include the western and eastern sections of the Hopi reservation, respectively) first peaked at the end of June. ${ }^{14}$ Cases for Navajo Nation and other surrounding jurisdictions were abstracted from publicly available data. ${ }^{13} 14$

Between 30 July and 17 August, no Hopi cases were reported by either of the main healthcare centres; in comparison, 197 cases were diagnosed in June and 93 in July. At the end of July, Arizona daily cases were still above $50 \%$ of peak levels, and incidence in the Navajo Nation was still $25 \%$ of peak levels seen in May. During August, average daily incidence in the Navajo Nation as well as Arizona as a whole declined but less dramatically than among Hopi. The Hopi stay-at-home order expired in the second week of September. The Navajo Nation stayat-home order (enacted $20 \mathrm{March}$ ) had expired in the second week of August, whereas the state of Arizona stayat-home order (enacted 31 March) expired on 15 May.

\section{Public health systems strengthening}

In May, the Hopi Tribe requested assistance from the US Centers for Disease Control and Prevention (CDC), and a team was deployed on 18 May to support response activities. The following section describes the systems strengthened during the first wave (table 1).

\section{Response coordination}

On 17 March 2020, although no cases had yet been diagnosed on the Hopi reservation, the Hopi Tribe activated the Hopi Emergency Response Team (HERT). HERT-led activities primarily focused on logistical support of Hopi villages and communities, such as providing resources and services (eg, food and medical transportation to persons in isolation or quarantine) while also facilitating communication and situational awareness. Village leaders acted independently in late March and early April to enact stayat-home orders, security checkpoints or business closures for their villages. These measures were continued and, in many cases, strengthened throughout the summer and autumn.

To increase coordination between the Hopi Tribe and HHCC and ensure broader COVID-19 awareness, weekly 'tripod' calls were begun in late May. These calls include participants from the Hopi government, IHS (including HHCC and the area office) and CDC and have continued throughout the pandemic. In mid-June, as cases rose and response activities increased, the Hopi Tribe decided to create a joint emergency response plan to formalise 
Table 1 Overview of principal measures

\begin{tabular}{|c|c|c|}
\hline Category & Measures & Month initiated \\
\hline \multirow{2}{*}{$\begin{array}{l}\text { Emergency response } \\
\text { coordination }\end{array}$} & Activation of the Hopi Emergency Response Team & March \\
\hline & Establishment of Hopi Incident Management Authority & August \\
\hline \multirow{6}{*}{$\begin{array}{l}\text { Community mitigation and } \\
\text { infection prevention and } \\
\text { control (IPC) }\end{array}$} & $\begin{array}{l}\text { Standardised entry symptom screening for staff and patients at Hopi } \\
\text { Health Care Center }\end{array}$ & May \\
\hline & $\begin{array}{l}\text { IPC training with the National Guard, for health facility and tribal } \\
\text { government staff }\end{array}$ & May \\
\hline & COVID-19 mitigation guidelines for ceremonies and burials & June \\
\hline & $\begin{array}{l}\text { Development of and training on COVID-19 readiness checklists for safe } \\
\text { reopening of businesses, schools and other facilities }\end{array}$ & May \\
\hline & $\begin{array}{l}\text { Referrals of ambulatory patients with COVID-19 to an outside isolation } \\
\text { facility }\end{array}$ & June \\
\hline & $\begin{array}{l}\text { Development of COVID-19 cleaning and disinfection protocols for facilities } \\
\text { reporting a case of COVID-19 }\end{array}$ & June \\
\hline \multirow[t]{3}{*}{$\begin{array}{l}\text { Epidemiology and } \\
\text { Surveillance }\end{array}$} & $\begin{array}{l}\text { Daily reporting of case information from Hopi Health Care Center to Hopi } \\
\text { Tribe }\end{array}$ & March \\
\hline & Public reporting of COVID-19 case numbers & May \\
\hline & Weekly surveillance reporting from health facilities to Hopi Tribe & July \\
\hline \multirow[t]{7}{*}{ Communications } & COVID-19 Hotline & March \\
\hline & Toolkits for village leaders & March \\
\hline & COVID-19 radio show (Hopi Health Care Center) & March \\
\hline & Enhanced multimedia communications: radio, Facebook and print & $\begin{array}{l}\text { March (intensified } \\
\text { in May) }\end{array}$ \\
\hline & Public health town halls & April and August \\
\hline & Communications plan and strategy developed & May-June \\
\hline & Community outreach programme (CHAC) & June \\
\hline
\end{tabular}

CHAC, Community Outreach, Health Education, Assessment for COVID-19, Connection to Testing and Care.

and streamline roles and responsibilities across partners. With CDC support, on 7 August, the Hopi Incident Management Authority (HIMA) was established to strategically oversee COVID-19 response and reopening plans. HIMA meets weekly, working with tribal response partners (the tribal government, HHCC, HERT and school administrators) to discuss response objectives, provide updates and determine channels to disseminate health messaging to the public. Additionally, HIMA determines future needs and activities to support reopening of tribal offices, schools and community organisations. The creation of HIMA enabled swift and coordinated response, consistent information-sharing among stakeholders and harmonised implementation of initiatives. HIMA regularly reviews available scientific information and incorporates relevant data points into response decision making.

Community mitigation and infection prevention and control (IPC) Initial response efforts focused on improving IPC within the healthcare setting (eg, entry symptom screening for patients and staff, coordinating with the National Guard to provide IPC training) and on translating CDC IPC recommendations to the Hopi context. A key IPC-related challenge was isolation and quarantine in the multigenerational households common among Hopi people. ${ }^{15} 16$ Households can be large, sometimes comprising $\geq 10$ people living in just one or two rooms. Furthermore, not all households have indoor plumbing, and some share bathing facilities or outhouses with other families. In these small, shared spaces, it can be difficult or impossible to follow guidelines such as having ill people sleep in a separate bedroom or use a separate bathroom. ${ }^{17} 18$ In late June, the Hopi Tribe began referring ambulatory patients with COVID-19 to an isolation facility in Flagstaff, Arizona; there, individuals would receive free food and lodging during their isolation. From 1 July to 10 August, approximately 13 individuals used this service. For patients with COVID-19 who preferred to isolate at home near family, resource kits were provided that included food, water and cleaning supplies. Patients received guidance on how to isolate from uninfected family members, including detailed information on practicalities such as dining, laundry and cleaning. Guidance explained how to separate sleeping spaces using hung sheets or blankets, included considerations for caregiving 
responsibilities and reminded patients about hand hygiene, social distancing and mask wearing. Additionally, guidance was distributed to well community members during community outreach activities.

Continuing safe practice of cultural traditions has been a critical concern of tribal response activities, especially since several major Hopi ceremonies typically take place in June and July, when cases were surging. Many Hopi ceremonies traditionally involve larger gatherings and include singing, dancing, sharing food and drink and/or spending extended amounts of time in close proximity and/or enclosed settings. Many Hopi elected to delay or forego traditional ceremonies and gatherings. However, recognising that some may not find it acceptable to indefinitely postpone ceremonies, the Hopi Tribe worked with CDC to develop practical guidance on how ceremonies could be modified to mitigate SARS-CoV-2 transmission risk. Guidelines focused on three main areas: (1) personal protective measures (hand washing, cough etiquette and mask wearing), (2) social distancing (maintaining distance between individuals or encouraging those at higher risk of severe outcomes from COVID-19 (eg, older adults) to stay home or limit participation to outdoors activities) and (3) object and surface cleaning (rooms/ areas, ceremonial objects and clothes and any other hightouch items). Guidelines were made available to village leadership on 30 June. In July, three villages held major ceremonies, all of which were modified to some extent (only one was open to persons from outside the village); individual adherence to mitigation measures was mixed. Practical guidance was also developed for safe burial practices, including guidelines for use of personal protective equipment as well as recommendations on which practices may be less safe for participants at increased risk of severe COVID-19 outcomes.

An element of IPC critically important for reopening plans was the development of a cleaning and disinfection protocol for offices and other facilities reporting a case of COVID-19. Specific instructions were developed regarding cleaning materials, locations and timelines. This guidance was critical to ensure safety, efficient use of resources and continuity of operations.

\section{Epidemiology and surveillance}

In March and April, no data sharing agreement was in place between HHCC and the Hopi Tribe, and the Tribe did not have a designated Public Health Authority for receiving protected health information. For this reason, HHCC regularly shared with the Hopi leadership only aggregate numbers of tests and test results; systems were not in place to share information such as trends in cases, percent positivity or testing capacity. This lack of epidemiological information made it difficult for both leadership and the public to understand COVID-19 risk among Hopi.

In May, after the Hopi designated a Public Health Authority, data-sharing agreements were implemented with HHCC and TCRHCC, and the Hopi Tribe began to receive detailed case-based data. The Hopi Tribe made public the number of COVID-19 cases by village; these data were shared on the Tribal website and the Facebook page of the Hopi radio station KUYI. This information provided important input into tribal leadership decisions as well as village-level decisions about whether to reopen offices or implement mitigation protocols such as curfews. There was also a high level of engagement with the posts by community members; it is possible that seeing these data helped community members take the pandemic more seriously.

In early July, CDC designed and deployed a semiautomated data analysis tool at HHCC to facilitate weekly distribution of a standardised surveillance report to the Hopi Tribe. This tool uses data extracted from HHCC medical records, thus reducing staff burden by not requiring additional data entry or manual data analysis. These reports summarised the state of the epidemic with analysis of case trajectories and positivity rates, thereby providing leadership with necessary data points for reopening decisions. In July, the tribe, HHCC and TCRHCC formalised agreements to share summarised data on a weekly basis.

\section{Community outreach and education}

During contact tracing performed April to mid-June, several barriers to mitigating community transmission were noted: symptomatic persons often delayed care and testing, community adherence to preventive behaviours such as mask wearing and social distancing was inconsistent and many community members had limited understanding of isolation and quarantine procedures. ${ }^{15}$ In response to these findings, the Hopi Tribe collaborated with HHCC and CDC to design and implement a programme to enhance COVID-19 case finding and provide COVID-19 focused health education directly to community members. ${ }^{16}$ This programme built on the existing foundation of the tribe's Community Health Representative (CHR) Programme (which delivers basic health education and follow-up screening), and HHCC's Community Health Department programmes (which are guided by the known social determinants of health for the reservation (eg, literacy, transportation and availability of running water)). Additionally, the programme incorporated input from community leaders as well as learnings from CDC-provided trainings on contact tracing, case investigation and community outreach.

As part of this new programme, termed Community Outreach, Health Education, Assessment for COVID-19, Connection to Testing and Care (CHAC), CHRs partnered with community volunteers to attempt to reach every household in each village to provide education on COVID-19 prevention strategies (hand hygiene, mask wearing, social distancing and appropriate isolation and quarantine) and screen household members for potential symptoms of COVID-19; persons with COVID-like symptoms or COVID-19 exposure are referred to HHCC for testing. Each household receives educational material 


\begin{tabular}{|c|c|c|}
\hline Title & Content/objective & Format \\
\hline $\begin{array}{l}\text { Caring for Someone Sick at } \\
\text { Home }\end{array}$ & $\begin{array}{l}\text { Practical information on how to care for somebody with COVID-19 at } \\
\text { home, while protecting self and others from infection, for example, } \\
\text { considerations for the following: } \\
\text { Eating and drinking. } \\
\text { Laundry. } \\
\text { Caregiving. } \\
\text { Mask usage. } \\
\text { Also includes contact information for key resources (eg, COVID-19 } \\
\text { hotline, police and transportation). }\end{array}$ & $\begin{array}{l}\text { Laminated booklet } \\
\text { bound together with } \\
\text { O-ring. }\end{array}$ \\
\hline 10 Things You Can Do at Home & $\begin{array}{l}\text { Simple, one-page document outlining key COVID-19 prevention } \\
\text { messages applicable for sick and well people, for example, staying } \\
\text { home, calling the healthcare centre for any new symptoms, wearing a } \\
\text { mask, cough and hand hygiene. }\end{array}$ & Single page flyer \\
\hline $\begin{array}{l}\text { Community Health } \\
\text { Representative Program } \\
\text { Newsletter }\end{array}$ & $\begin{array}{l}\text { Short newsletter with visual information about COVID-19 prevention } \\
\text { and key updates for Hopi (eg, executive order dates). Past topics } \\
\text { include grief, quarantine versus isolation, correct usage and removal } \\
\text { of gloves, and do's and don't's for mask wearing. }\end{array}$ & $\begin{array}{l}\text { One page double- } \\
\text { sided }\end{array}$ \\
\hline
\end{tabular}

All materials were developed or adapted for Hopi and include plain language and increased graphics.

(eg, newsletter, flyer and laminated flipbook of information); these materials also include contact information for tribal services such as non-emergency transport (table 2; online supplemental figure 1). All villages were canvassed at least once between late June and late August. Eighthundred thirty-nine households (of 1308 approached) participated, representing over 2900 people; 6\% of households refused, and in $30 \%$ of households, nobody was home to be interviewed. Thirteen symptomatic or potentially exposed persons were referred for testing at HHCC.

\section{Communications}

In May and early June, the Hopi Tribe collaborated with HHCC and CDC to develop a COVID-19 specific communications plan. The plan built on existing activities and outlined the specific communications channels, key content and messages, and innovative strategies to maximise engagement.

Dissemination of health information through multiple platforms in Hopi as well as English was key to broadening reach and impact. Although most people on the reservation speak English as a primary language and have access to the internet, a small but important proportion of the population is most comfortable communicating in Hopi and is less likely to get information online; many of these persons are older and thus at higher risk of severe outcomes from COVID-19. For this reason, in-person messaging (eg, by CHRs via the CHAC programme) and Hopi language radio segments are critical elements of the communications plan. In addition to the Hopi radio station (KUYI (https://www.kuyi.net/)), the following mass media channels are used to disseminate COVID-19 related messaging: Facebook (primarily via the KUYI page), the Hopi Tribe website, newspapers (including the
Hopi tribal newspaper, Tutuveni) and newsletters (such as the CHR newsletter and village newsletters). Flyers and posters have been developed for display at HHCC and other public places like village bulletin boards; educational material was also distributed to village administrators for handout to residents. Lastly, the HHCC COVID-19 hotline, established on 18 March, provides basic health education related to COVID-19 and also connects individual callers to resources and care.

Key messages cover four main themes: basic prevention (hand hygiene, social distancing, mask wearing, cough hygiene, frequent cleaning and disinfecting and staying home while sick), basics of COVID-19 transmission (eg, between persons in close contact, by symptomatic and asymptomatic persons), groups at higher risk of severe outcomes (eg, older persons and persons with comorbidities) and how and when to isolate and quarantine. Specific messaging was also developed based on community feedback to address testing (where, when and why), stigma and how to protect family members at higher risk. Messaging was developed for specific groups (eg, youths and older adults) and ideas (eg, how breaking mitigation guidelines 'just a little' can still be risky).

Development of fresh content was an important part of the communications strategy, encouraging consistent community engagement. Each week, KUYI airs an HHCC-hosted radio show with rotating COVID-19 related topics; these topics are updated in response to recent or upcoming events (eg, holidays and CHAC canvasses). Furthermore, KUYI frequently updates its Facebook page with the latest COVID-19 case numbers as well as videos (in Hopi and English) with COVID-19 prevention messages. One particularly well-received KUYI campaign featured an interview with a woman 


\begin{tabular}{|c|c|c|c|c|}
\hline \multirow[t]{2}{*}{ Phase } & \multicolumn{3}{|l|}{ Guidelines For... } & \multirow{2}{*}{$\begin{array}{c}\text { Criteria for moving to the } \\
\text { next phase (ALL must be } \\
\text { met) ... }\end{array}$} \\
\hline & Individuals & Employers & Specific Situations & \\
\hline $\begin{array}{l}\text { Phase } 0 \\
\text { (Shelter- } \\
\text { in-Place } \\
\text { [SIP]) }\end{array}$ & $\begin{array}{l}\text { - Except for essential } \\
\text { personnel or essential } \\
\text { activities, stay at home } \\
\text { - } \quad \text { No unnecessary travel } \\
\text { - } \quad \text { Wear masks, keep distance, } \\
\text { and avoid crowds } \\
\text { - } \quad \text { No visitors or tourists }\end{array}$ & $\begin{array}{l}\text { - Except for essential } \\
\text { businesses, cease all in- } \\
\text { person activities } \\
\text { - Essential businesses may } \\
\text { continue to operate with } \\
\text { social distancing }\end{array}$ & $\begin{array}{l}\text { Restaurants and food- } \\
\text { service limited to takeout } \\
\text { only } \\
\text { Short-term lodging must } \\
\text { cease operations unless } \\
\text { providing } \\
\text { quarantine/isolation or } \\
\text { hosting emergency } \\
\text { responders }\end{array}$ & \multirow{2}{*}{$\begin{array}{l}\text { Downward trajectory } \\
\text { (or near-zero) of } \\
\text { percent positivity (viral } \\
\text { diagnostic tests) over a } \\
\text { 14-day period (flat or } \\
\text { increasing volume of } \\
\text { tests). } \\
\text { Percent positivity } \\
<20 \% \text { for } 14 \text { days. } \\
\text { Adequate staff and } \\
\text { PPE supplies to handle } \\
\text { hospital admissions. } \\
\text { Ability to test all first } \\
\text { responders, healthcare } \\
\text { personnel, and } \\
\text { contacts of COVID-19 } \\
\text { positive individuals. }\end{array}$} \\
\hline Phase 1 & $\begin{array}{l}\text { - Individuals at increased risk } \\
\text { of severe outcomes* } \\
\text { should continue SIP } \\
\text { - } \quad \text { Only essential travel is } \\
\text { permitted } \\
\text { - Wear masks, keep distance, } \\
\text { and avoid crowds } \\
\text { - } \quad \text { Avoid groups of }>10\end{array}$ & $\begin{array}{l}\text { - Encourage telework where } \\
\text { possible } \\
\text { - } \quad \text { Prioritize return to work for } \\
\text { government, childcare, and } \\
\text { elementary schooling } \\
\text { - Close common areas } \\
\text { - } \quad \text { Minimize travel } \\
\text { - } \quad \text { Consider accommodations } \\
\text { for those at increased risk }\end{array}$ & $\begin{array}{l}\text { - Organized youth activities } \\
\text { are closed } \\
\text { - Schools remain closed } \\
\text { except as previously } \\
\text { discussed } \\
\text { - Visits to long-term care } \\
\text { facilities and hospitals } \\
\text { prohibited } \\
\text { - Large gatherings may } \\
\text { operate under strict } \\
\text { distancing and sanitation, } \\
\text { with universal masking }\end{array}$ & \\
\hline Phase 2 & $\begin{array}{ll}\text { - } & \text { Individuals at increased risk } \\
\text { of severe outcomes* } & \\
\text { should continue SIP } \\
\text { - } \quad \text { Travel may resume } \\
\text { - } \quad \text { Wear masks, keep distance, } \\
\text { and avoid crowds } \\
\text { - } \quad \text { Avoid groups of }>10\end{array}$ & $\begin{array}{ll}\text { - } & \text { Encourage telework where } \\
\text { possible } \\
\text { - } & \text { Close common areas } \\
\text { - } & \text { Travel may resume } \\
\text { - } & \text { Consider accommodations } \\
& \text { for those at increased risk }\end{array}$ & $\begin{array}{l}\text { Schools and organized } \\
\text { youth activities may } \\
\text { reopen with distancing and } \\
\text { sanitation precautions } \\
\text { - Visits to long-term care } \\
\text { facilities and hospitals may } \\
\text { resume under special } \\
\text { circumstances } \\
\text { - Large gatherings may } \\
\text { operate with distancing } \\
\text { and sanitation } \\
\text { Elective surgeries may } \\
\text { resume }\end{array}$ & $\begin{array}{l}\text { 6) Ability to provide test } \\
\text { results within time } \\
\text { frame for each } \\
\text { reopening phase: } \\
\text { (Phase } 1: \leq 3 \text { days, } \\
\text { Phase } 2: \leq 2 \text { days, Phase } \\
3: \leq 2 \text { days) } \\
\text { 7) Communication plan } \\
\text { regarding reopening }\end{array}$ \\
\hline Phase 3 & $\begin{array}{l}\text { Individuals at increased risk } \\
\text { of severe outcomes* may } \\
\text { resume public activities, } \\
\text { with distancing, masking, } \\
\text { and avoiding crowds } \\
\text { - Others should also avoid } \\
\text { crowds }\end{array}$ & $\begin{array}{l}\text { - Unrestricted staffing may } \\
\text { resume, with } \\
\text { demonstration of proper } \\
\text { environmental controls to } \\
\text { maximize distancing and } \\
\text { protect staff }\end{array}$ & $\begin{array}{l}\text { Visits to long-term care } \\
\text { facilities and hospitals may } \\
\text { resume, with special } \\
\text { attention to sanitation and } \\
\text { distancing } \\
\text { Large gatherings may } \\
\text { operate with distancing } \\
\text { and sanitation }\end{array}$ & $\begin{array}{l}\text { 1) Sustained increase in } \\
\text { COVID-19 cases over } \\
\text { past } 14 \text { days } \\
\text { 2) Sustained increase in } \\
\text { percent positivity over } \\
\text { past } 14 \text { days }\end{array}$ \\
\hline
\end{tabular}

Figure 3 Reopening plan overview. This figure shows the phases associated with the Hopi reopening plan, including the guidelines for individuals, employers and specific situations. The right-hand side of the figure outlines the criteria for moving between phases. *Individuals at increased risk of severe outcomes include older persons and those with comorbidities.

who developed COVID-19 but strictly followed isolation guidelines and was able to prevent transmission to her family even though they lived in a small, one-room house. Campaigns focused on safe celebrations were developed and disseminated in advance of holidays (eg, Memorial Day and July 4 weekends and Halloween). The frequency of message delivery was increased in response to case counts. All communications content is archived and has also been made available to other tribes for adaptation and use.

\section{Reopening plans}

During May-July, the Hopi Tribe worked to create a phased reopening plan (figure 3 ). The reopening plan included: (1) criteria to begin reopening; (2) criteria for advancing between reopening phases; (3) activities permitted at each phase; and (4) checklists for communities, businesses and schools, and other essential services to safely resume services. ${ }^{19-21}$ Task groups were created and trained on how to assess and mitigate risks associated with facility reopening. Task group members then trained others to conduct site-specific risk assessments and create appropriate strategies. All reopening plans were sensitive to the unique aspects of the Hopi context, in particular the frequency of extended family gatherings and the fact that some communities have limited access to water, which complicates the enhanced hygiene practices recommended for COVID-19 risk mitigation.

From July to August, the Hopi Tribe focused on planning for school reopening. Assessment checklists and processes were reviewed with school administrators, and initial assessments were conducted at seven schools. Tribal officials were trained on school assessments and worked with CDC to define postassessment protocols and align mitigationassociated resource needs with funding sources. ${ }^{22}$

By mid-August, HIMA was fully operational, and Hopi COVID-19 response activities were continuing under the guidance of this leadership body. Based on the declining case trends in August and early September, the Hopi Tribe decided to reopen government facilities and to allow phased and restricted reopening of other businesses on 11 September 2020 and allowed phased return to work subject to mandatory mask usage and a nightly curfew. 
TESTING THE SYSTEM: IMPACT OF IMPROVED CAPACITY ON RESPONSE TO THE SECOND WAVE

\section{Epidemiological situation (second wave)}

Beginning in the third week of September, there was an increase in cases on the Hopi reservation; average daily incidence increased to $>20$ per 100000 population by mid-October, with intermittent lulls but no clear downward trend. Concurrent incidence in the Navajo Nation as well as the state of Arizona was approximately 10 per 100000 population. On 9 November, when it was evident that cases were consistently increasing, Hopi Tribal leadership implemented a stay-at-home order, which halted the return-to-work plan with an exception for essential workers; this order was to remain in effect until criteria from the Hopi reopening plan were met (including evidence of a downward case trajectory for 14 days). By mid-November, daily incidence figures in Hopi as well as Arizona averaged $>30$ cases per 100000 population, while daily incidence in the Navajo Nation had climbed to $>50$ cases per 100000 .

\section{Response activities}

Because regular surveillance reporting from HHCC and TCRHCC was in place, Hopi leadership was quickly alerted on 16 September of the recent increase in cases. With the knowledge that one case can quickly lead to others, Hopi leadership responded immediately. On 17 September, the Hopi Tribe released a video message from the Chairman wherein he discussed the recent rise in cases and urged the community to recommit to mitigation guidelines.

Recognising the potential impact of in-person outreach and communications, particularly for persons not accessing mass media, the Hopi Tribe prepared for a new round of CHAC canvasses in mid-September. Using data from surveillance reporting, Hopi leadership was able to identify villages in which recent increases had been reported and prioritise those villages for the first CHAC canvasses. CHAC has been instrumental in the response as a means of directly connecting with the communities to refer symptomatic individuals to testing and provide up-to-date guidance and information about the pandemic. Not all Hopi access mass media on a regular basis, so in-person messaging and education from trusted community members are invaluable. As influenza season began, materials were revised to include guidance on influenza as well as COVID-19. Unfortunately, due to staffing challenges, CHAC canvasses did not proceed on a regular schedule through all villages until December 2020.

Mass media communications efforts were again scaled up in the second wave, drawing on the experiences gained during the first wave regarding frequency and content. HHCC increased its radio show to run twice weekly with new content, and the Hopi Tribe continued to share and amplify content related to COVID-19 cases and prevention via KUYI radio and Facebook. A focused email campaign was also developed for tribal government workers. The tribe also posted new content on its website, including an expanded surveillance report developed by the new staff epidemiologist (hired in September).

On 9 November, in reaction to continuing cases on the reservation, and with full consideration of how to best engage and support response and community, Hopi Tribal leadership implemented a revised stay-at-home order, halting the return-to-work plan. This action was informed by the guidelines of the phased reopening plan, which also guide decisions around when to reopen. Due to improved resourcing and organisation of Hopi Law Enforcement Services, enforcement of the stay-athome order (eg, via issuing citations to non-compliers) has increased, further slowing unnecessary movement between villages. Response coordination across the 12 village governments remains challenging, but the existence of HIMA helps to ensure aligned efforts, even in the face of a rapidly changing epidemiological situation. Consistent messaging across entities (including village leadership, tribal leadership and HHCC) is paramount, as is in-person communication.

\section{CONCLUSION}

The Hopi Tribe, a sovereign nation with a small population, was disproportionately affected by the first wave of the COVID-19 pandemic in June and July, with 7-day average daily incidence during the peak of the epidemic more than twice the incidence for the state of Arizona. The Hopi Tribe worked tirelessly with federal partners and communities to respond to the pandemic by implementing surveillance, response coordination and communication systems. These efforts-of the tribal government, federal partners and community members-contributed to the decreasing case trends and the observed break in community transmission in August. Unfortunately, due to the remoteness of the Hopi reservation, residents must travel outside its borders to obtain certain goods and services, making the Hopi vulnerable to imported infections. During September-November, as cases rose across the USA, cases also increased in Hopi, testing the response system. Equipped with comprehensive systems and data, the Hopi Tribe quickly reacted by scaling up communications efforts, providing education to the communities and implementing data-driven guidelines and mitigation activities. These efforts may have delayed the increase in cases relative to surrounding areas, but continued vigilance, transparent information sharing and efforts to build trust will continue to be necessary among all partners. As vaccines against COVID-19 become broadly available, community outreach will be critical; accurate information from trusted individuals will be important to increase vaccine uptake. ${ }^{23}$

The experience of the pandemic has highlighted the importance of a strong public health infrastructure, and the Hopi Tribal Government is committed to building this capacity. One specific focus will be to build out an epidemiology programme within the Hopi Department 
of Health and Human Services. Such a programme could work in coordination with the HHCC to strengthen the Hopi public health system by investing in the CHR programme and other programmes to serve the community. The programmes, plans, partnerships and guidelines put in place and strengthened in the early stages of the pandemic have proved useful in directing response activities and informing decisions during the second wave of cases on Hopi and also serve as a foundation towards improving the capacity of the Hopi public health system.

The Hopi are not unique among global indigenous peoples in facing the COVID-19 pandemic (or other infectious disease pandemics) with limited pre-existing public health infrastructure and while experiencing disproportionate impact. ${ }^{467924-27}$ However, the Hopi experience, among others (notably the experiences of indigenous populations in Australia and Canada), underlines the importance of relevant and timely epidemiological data, culturally specific health communications and response plans that are tailored to the cultural context and developed by and for the indigenous community. ${ }^{24} 28-31$ The COVID-19 pandemic has presented an especially urgent threat to indigenous communities: the increased vulnerability of older persons to severe outcomes from the disease presents a risk not just to individuals but also to the entire way of life of communities, given the role of elders as keepers of traditional knowledge among many indigenous peoples. It is our hope that the experiences described in this report might be useful in informing the responses of other indigenous communities to COVID-19 as well as to future infectious disease pandemics.

\section{Author affiliations \\ ${ }^{1}$ Hopi Tribe, Kykotsmovi, Arizona, USA \\ ${ }^{2}$ COVID-19 Response, Centers for Disease Control and Prevention, Atlanta, Georgia, USA \\ ${ }^{3}$ National Institute for Occupational Safety and Health, Centers for Disease Control and Prevention, Cincinnati, Ohio, USA \\ ${ }^{4}$ Hopi Health Care Center, Polacca, Arizona, USA \\ Acknowledgements The authors would like to acknowledge the employees of the Hopi Tribe, the Hopi Health Care Center and the Tuba City Regional Health Care Center. We would also like to acknowledge the Hopi village leadership and village administrators, as well as the community members. Finally, we are also grateful for the support and input of the Centers for Disease Control and Prevention (CDC) COVID-19 Response Team.}

Contributors $\mathrm{SAB}, \mathrm{RB}, \mathrm{DH}$ and TLN conceptualised the report. RB, SAB, HK, and $\mathrm{DH}$ drafted the report. $\mathrm{RB}$ and $\mathrm{HK}$ made the figures and tables. KF drafted the supplementary material. All authors made substantial contributions to the work described herein and reviewed and revised the report as written. All authors approved the final version.

Funding The work described in this report was performed as part of the normal duties and responsibilities of the federal and tribal employees described. No additional funding was sought or received to support the write-up of this work.

Disclaimer The findings and conclusions in this report are those of the authors and do not necessarily represent the official position of the U.S. Centers for Disease Control and Prevention or the Indian Health Service.

Map disclaimer The depiction of boundaries on the map(s) in this article does not imply the expression of any opinion whatsoever on the part of BMJ (or any member of its group) concerning the legal status of any country, territory, jurisdiction or area or of its authorities. The map(s) are provided without any warranty of any kind, either express or implied.
Competing interests None declared.

Patient consent for publication Not required.

Ethics approval This activity was reviewed by $\mathrm{CDC}$ and was conducted consistent with applicable federal law and CDC policy: 45 C.F.R. part 46.102(I)(2), 21 C.F.R. part 56; 42 U.S.C. Sect. 241(d); 5 U.S.C. Sect. 552a; 44 U.S.C. Sect. 3501 et seq.

Provenance and peer review Not commissioned; externally peer reviewed.

Data availability statement Some data are publicly available but some data are private and cannot be released.

Supplemental material This content has been supplied by the author(s). It has not been vetted by BMJ Publishing Group Limited (BMJ) and may not have been peer-reviewed. Any opinions or recommendations discussed are solely those of the author(s) and are not endorsed by BMJ. BMJ disclaims all liability and responsibility arising from any reliance placed on the content. Where the content includes any translated material, BMJ does not warrant the accuracy and reliability of the translations (including but not limited to local regulations, clinical guidelines, terminology, drug names and drug dosages), and is not responsible for any error and/or omissions arising from translation and adaptation or otherwise.

Open access This is an open access article distributed in accordance with the Creative Commons Attribution Non Commercial (CC BY-NC 4.0) license, which permits others to distribute, remix, adapt, build upon this work non-commercially, and license their derivative works on different terms, provided the original work is properly cited, appropriate credit is given, any changes made indicated, and the use is non-commercial. See: http://creativecommons.org/licenses/by-nc/4.0/.

ORCID iD

Rachel M. Burke http://orcid.org/0000-0002-5678-5826

\section{REFERENCES}

1 The Hopi Tribe official website, 2020. Available: https://www.hopinsn.gov/ [Accessed 10 Aug 2020].

2 Hatcher SM, Agnew-Brune C, Anderson M, et al. COVID-19 Among American Indian and Alaska Native Persons - 23 States, January 31-July 3, 2020. MMWR Morb Mortal Wkly Rep 2020;69:1166-9.

3 Arrazola J, Masiello MM, Joshi S, et al. COVID-19 Mortality Among American Indian and Alaska Native Persons - 14 States, JanuaryJune 2020. MMWR Morb Mortal Wkly Rep 2020;69:1853-6.

4 Kakol M, Upson D, Sood A. Susceptibility of southwestern American Indian tribes to coronavirus disease 2019 (COVID-19). J Rural Health 2021;37:197-199.

5 Warne D, Frizzell LB. American Indian health policy: historical trends and contemporary issues. Am J Public Health 2014;104 Suppl 3:S263-7.

6 Rodriguez-Lonebear D, Barceló NE, Akee R, et al. American Indian Reservations and COVID-19: correlates of early infection rates in the pandemic. J Public Health Manag Pract 2020;26:371-7.

7 Yellow Horse AJ, Yang T-C, Huyser KR. Structural inequalities established the architecture for COVID-19 pandemic among native Americans in Arizona: a geographically weighted regression perspective. J Racial Ethn Health Disparities 2021. doi:10.1007/ s40615-020-00940-2. [Epub ahead of print: 19 Jan 2021].

8 Broken promises: continuing federal funding shortfall for native Americans. Washington, DC U.S. Commission on Civil Rights; 2018. https://www.usccr.gov/pubs/2018/12-20-Broken-Promises.pdf

9 Hathaway ED. American Indian and Alaska native people: social vulnerability and COVID-19. J Rural Health 2021;37:256-9.

10 Risk for COVID-19 infection, hospitalization, and death by Race/ Ethnicity, 2021. Available: https://www.cdc.gov/coronavirus/2019ncov/covid-data/investigations-discovery/hospitalization-death-byrace-ethnicity.html [Accessed 14 Mar 2021].

11 Close RM, Stone MJ. Contact tracing for native Americans in rural Arizona. N Engl J Med 2020;383:e15.

12 Kovich H. Rural Matters - Coronavirus and the Navajo Nation. N Engl $J$ Med 2020;383:105-7.

13 Navajo Nation COVID-19 Dashboard, 2020. Available: https://www. ndoh.navajo-nsn.gov/COVID-19/Data [Accessed 15 Dec 2020].

14 USAFacts. US coronavirus cases and deaths, 2020. Available: https://usafacts.org/visualizations/coronavirus-covid-19-spreadmap/

15 Hirschman J, Kaur H, Honanie K, et al. A SARS-CoV-2 Outbreak Illustrating the Challenges in Limiting the Spread of the Virus - Hopi Tribe, May-June 2020. MMWR Morb Mortal Wkly Rep 2020;69:1654-9. 
16 Jenkins R, Burke RM, Hamilton J, et al. Notes from the Field: Development of an Enhanced Community-Focused COVID-19 Surveillance Program - Hopi Tribe, June-July 2020. MMWR Morb Mortal Wkly Rep 2020;69:1660-1.

17 CDC. Households living in close quarters, 2020. Available: https:// www.cdc.gov/coronavirus/2019-ncov/daily-life-coping/living-inclose-quarters.html

18 CDC. What to do if you are sick, 2020. Available: https://www.cdc gov/coronavirus/2019-ncov/if-you-are-sick/steps-when-sick.html [Accessed 1 Sep 2020].

19 AlHA. Reopening: guidance for general office settings; 2020. https://aiha-assets.sfo2.digitaloceanspaces.com/AlHA resources/Reopening-Guidance-for-General-Office-Settings GuidanceDocument.pdf

20 CDC. Resuming business toolkit, 2020. Available: https://www.cdc. gov/coronavirus/2019-ncov/community/resuming-business-toolkit. html [Accessed 20 May 2020].

$21 \mathrm{CDC}$. Interim guidance for businesses and employers responding to coronavirus disease 2019 (COVID-19), 2020. Available: https://www. cdc.gov/coronavirus/2019-ncov/community/guidance-businessresponse.html [Accessed 20 May 2020].

22 CDC. Schools and child care programs. 2020. Available: https:// www.cdc.gov/coronavirus/2019-ncov/community/schools-childcare/

23 The Lancet . COVID-19 vaccines: no time for complacency. Lancet 2020;396:1607.

24 Mallard A, Pesantes MA, Zavaleta-Cortijo C, et al. An urgent cal to collect data related to COVID-19 and indigenous populations globally. BMJ Glob Health 2021;6:e004655.
25 Montag D, Barboza M, Cauper L, et al. Healthcare of indigenous Amazonian peoples in response to COVID-19: marginality, discrimination and revaluation of ancestral knowledge in Ucayali, Peru. BMJ Glob Health 2021;6:e004479.

26 Ibarra-Nava I, Flores-Rodriguez KG, Ruiz-Herrera V, et al. Ethnic disparities in COVID-19 mortality in Mexico: a cross-sectional study based on national data. PLoS One 2021;16:e0239168.

27 Lane R. The impact of COVID-19 on indigenous peoples United Nations Department of Economic and Social Affairs; 2020. https:// www.un.org/development/desa/dpad/wp-content/uploads/sites/45/ publication/PB_70.pdf

28 Rosenthal EL, Menking P, Begay M-G. Fighting the COVID-19 Merciless monster: lives on the Line-Community health representatives' roles in the pandemic battle on the Navajo nation. J Ambul Care Manage 2020;43:301-5.

29 Allen B. Largest outbreak of COVID-19 in an Indigenous community in Canada offers important lessons, 2020. CBC News. Available: https://www.cbc.ca/news/canada/saskatchewan/outbreak-covid19-indigenous-community-lessons-1.5737126 [Accessed 29 Sep 2020].

30 Moodie N, Ward J, Dudgeon P, et al. Roadmap to recovery: reporting on a research taskforce supporting indigenous responses to COVID-19 in Australia. Aust J Soc Issues 2020. doi:10.1002/ ajs4.133. [Epub ahead of print: 2209 2020].

31 Eades S, Eades F, McCaullay D, et al. Australia's first nations' response to the COVID-19 pandemic. Lancet 2020;396:237-8. 